\title{
A Szociális Jogok Európai Pilléréről
}

\section{On European Pillar of Social Rights}

\author{
Szerző: Andor Csaba $\square$ \\ Emberi Erőforrások Minisztériuma
}

Beküldve: 2018. 02. 02.

doi: $10.24365 /$ ef.v59i1.232

Kulcsszavak: szociális pillér, Európai Unió, szociális eredménytábla, egészségpolitika

Keywords: social Pillar, European Union, social scoreboard, health policy

\section{BEVEZETÉS}

A Szociális Jogok Európai Pillére (szociális pillér, pillér) létrehozásának tervét - eredetileg az euróövezeten belüli országokra - Jean-Claude Juncker bizottsági elnök jelentette be 2015 szeptemberében. A 2016 decemberében lezárult nyilvános konzultáció után az Európai Bizottság 2017. április 26án tette közzé a pillér létrehozását célzó végleges javaslatcsomagját. A kezdeményezés alapvetően a munkaerőpiac és a szociális jóléti rendszerek múködtetését célzó lényeges jogokat, alapelveket kívánja megerősíteni és továbbfejleszteni három témában húsz szakpolitikai területen. Az egyes területeken az előrehaladást az ún. szociális eredménytáblával méri.

A pillér alapját a három uniós jogalkotó intézmény (Európai Parlament, Tanács, Bizottság) által 2017. november 17-én, Göteborgban ünnepélyesen kihirdetett politikai dokumentum, egy ún. intézményközi proklamáció képezi, amely ugyan jogi kötőerővel nem bír, de a vele egyetértő tagállamok elfogadják céljait és az alapelveket mint politikai prioritásokat. Tehát politikai kötelezettségvállalásról van szó, amely egyfajta keretet ad az Európai Unió szociális pillérét alkotó munkajogi és szociális vívmányok (acquis) továbbfejlesztésére; a keretet az egyes tagállamok maguk töltik meg tartalommal.
A pillér jogi mintájául szolgáló Alapjogi Chartáról az Európai Tanács döntött az 1999-es kölni csúcson, kihirdetése a 2000. december 7-i nizzai csúcson történt. Az elfogadásakor jogi kötőerővel nem bíró Alapjogi Charta a Lisszaboni Szerződés 2009. december 1-jén történt hatályba lépésével az elsődleges uniós jogforrás része lett. Ez alapján vélelmezhető, hogy a pillért kihirdető és kötelező jogi erővel nem bíró intézményközi proklamáció is a jövőben a szerződések részévé válik. S annak ellenére, hogy az Alapjogi Charta 2000 és 2009 között nem bírt kötelező jogi erővel, az Európai Bíróság számos ítéletében azt segítségül híva értelmezte az uniós jogot.

\section{ELŐZMÉNYEK ÉS A KÖZÖS TÁRSADALOMPOLI- TIKA JELENE AZ EU-BAN}

A pillér szakpolitikai elődjéül több korábbi kezdeményezés is megemlíthető. Ilyen a szociális beruházási csomag, a 2010-ben elfogadott Európa 2020 Stratégia és céljai (köztük kiemelten a szegénység vagy társadalmi kirekesztettség kockázatának kitettek száma csökkentése), de persze maga a szociális Európa gondolata jóval korábban megjelent.

Nyugat-Európa jóléti rendszerei számos közös vonással rendelkeztek már a 20. század során (pl. a 
jóléti kiadások aránya és szerkezete, a társadalombiztosítás lefedettsége), amelyek egyes vélemények szerint olyan jelentősek voltak, hogy lehetővé vált egységes európai szociális modellről beszélni, ahogy ez meg is történt az 1980-as évek közepétől. Ezt az ismert dán szociológus, Gøsta Esping-Andersen tipológiája is alátámasztja, amely szerint a kontinentális Nyugat-Európa egésze a konzervatív-korporatista típusba tartozott, és csupán három skandináv ország került a szociáldemokrata és két angolszász ország a liberális modellbe, vagyis az akkori EU lakosságának kevesebb mint negyede tartozott ezekhez. Ráadásul az 1980-as évektől a konvergencia igen nagymértékű volt az országok között (sőt mára már szupranacionális jelleget öltött), miközben a jóléti megoldások igencsak eltértek más fejlett országok, illetve régiók (USA, Japán, Ausztrália, Délkelet-Ázsia) jóléti rendszereitôl. A szociálpolitika ugyan mindmáig nemzetállami hatáskörbe tartozik, de bizonyos, a foglalkoztatáshoz kapcsolódó szociális területeken már a Római Szerződés is egységes szabályozást vezetett be, az 1990-es évektől kezdve pedig a szociális törvénykezés egységesítése - például a nyitott koordináció és a szociális teljesítmény egységes mérése révén - új lendületet kapott.

A szociális dimenzió még hangsúlyosabbá tétele a Gazdasági és Monetáris Unió (GMU) mélyítése keretében merült fel először 2012-13-ban, egyik első kezdeményezője Herman van Rompuy, az Európai Tanács elnöke volt. Megjelent a GMU szociális dimenziójának megerősítéséről szóló bizottsági közlemény, és az Európai Tanács is többször tárgyalta a GMU mélyítését, amelynek teljes mértékben összhangban kell lennie az egységes piaccal. A háttérbeli viták, az egyet nem értés - és közben a görög válság - után 2015-ben az öt elnök (az Európai Bizottság, az Európai Parlament, az Európai Tanács, az Európai Központi Bank és az Eurócsoport elnökei) jelentése nyomán ismét előtérbe került a téma: a foglalkoztatási és szociális kérdéseknek nagyobb szerepet kell kapniuk az európai szemeszterben, és jól múködő munkaerőpiacokra van szükség. A jelentés egyben egy föderatív irányba történő elmozdulást is javasolt.

A szociális dimenzió előterébe kerülése annak a nézetnek az erősödését is jelzi, hogy a szociális szempontok önmagukban is érvényesítendő célokat jelentenek.
A Római Szerződések aláírásának 60. évfordulója alkalmából az állam- és kormányfók által 2017. március 25-én elfogadott, ún. Római Nyilatkozatnak az EU jövőjére vonatkozó egyik pontja szerint olyan Unióra van szükség, amely a fenntartható fejlődés alapjain nyugszik, és amely előmozdítja a gazdasági és társadalmi fejlődést, a kohéziót és a konvergenciát, ugyanakkor megőrzi a belső piac integritását.

\section{A PILLÉR TARTALMA}

A szociális pillérben foglalt 20 alapelv és jog a következő három fő dimenzióba sorolható:

- esélyegyenlőség és munkavállalási jog (cél a foglalkoztatási lehetőségek növelése, a különböző foglalkoztatási státuszok közötti átmenet megkönnyítése és az egyének foglalkoztathatósága javítása):

1. oktatás, képzés és egész életen át tartó tanulás,

2. nemek közötti egyenlőség,

3. esélyegyenlőség,

4. a foglalkoztatás aktív támogatása;

- tisztességes munkafeltételek (a jogok és kötelezettségek megfelelő egyensúlya, biztosítja a rugalmasság és a biztonság közötti egyenlőséget a munkahelyteremtés, a munkahelyteremtés és a vállalatok alkalmazkodóképességének megkönnyítése, valamint a társadalmi párbeszéd előmozdítása érdekében):

5. biztonságos és rugalmas foglalkoztatás,

6. megfelelő bérek,

7. tájékoztatás a munkaviszony feltételeirôl és elbocsátás esetén védelem,

8. Szociális párbeszéd és munkavállalói részvétel,

9. a munka és magánélet közötti egyensúly,

10. egészséges, biztonságos és megfelelően kialakított munkakörnyezet és adatvédelem;

- a szociális védelem és a társadalmi befogadás (cél a szociális védelmi juttatásokhoz és a magas színvonalú közszolgáltatásokhoz való hozzáférés biztosítása, amelyek elengedhetetlenek az emberhez méltó élethez és a munkaerőpiacon és általában, a társadalmi életben való részvételhez): 
11. gyermekgondozás és a gyermekek támogatása,

12. szociális védelem,

13. munkanélküli ellátás,

14. minimumjövedelem,

15. időskori jövedelem és nyugdíjak,

16. egészségügyi ellátás,

17. a fogyatékossággal élő személyek társadalmi befogadása,

18. tartós ápolás-gondozás,

19. lakhatás és segítségnyújtás a hajléktalanok számára,

20. alapvető szolgáltatásokhoz való hozzáférés.

Amint látható, a jelenlegi uniós szerződések értelmében a pillért alkotó számos alapelv, illetve jog tekintetében az Európai Uniónak nincs hatásköre az Európai Bizottság által javasolt tartalmú egyéni jogok meghatározására, mivel ezek a szabályozási területek alapvetően tagállami hatáskörbe tartoznak, és csak az ún. nyitott koordináció (open method of coordination, OMC) keretében valamint természetes piaci folyamatok mentén (például az árak és bérek folyamatos közeledése, jó gyakorlatok alkalmazása) történik konvergencia ezen területeken. Ilyen az összes szociális védelemre és társadalmi befogadásra vonatkozó elv.

\section{MÉRÉS, A SZOCIÁLIS EREDMÉNYTÁBLA}

A pillérben történt előrehaladást az ún. szociális eredménytáblával méri az Európai Bizottság, amelynek első, ideiglenes változata a 2018. évi Közös foglalkoztatási jelentésben (Joint Employment Report, JER) kerül felhasználásra, és egyelőre 14 kulcs(headline) indikátort tartalmaz. (A hivatalos indikátortábla a http://ec.europa.eu/eurostat/web/european-pillar-of-social-rights/indicators/scoreboard helyen olvasható.) Az Európai Bizottság eredeti javaslata még 14 kulcs- és 21 másodlagos indikátort, valamint bontásaikat tartalmazta, de az utóbbiak változó minősége - és a tagállamok tiltakozása miatt a tervezett másodlagos indikátorokat egyelőre nem használja az értékelésekben. Az indikátorok két kivétellel (bérek, aktív munkaerőpiaci eszközök) a már meglévő és alkalmazott értékelési eszköztárak - a foglalkoztatási teljesítmény monito- rozása (EPM, 3 indikátor), a szociális védelmi teljesítmény monitorozása (SPPM, 6), közös értékelési keretrendszer (JAF, 3) - részei.

A kulcsindikátorok dimenziónként a következők:

- esélyegyenlőség és munkavállalás:

○ korai iskolaelhagyás,

○ nők és férfiak foglalkoztatása közti különbség,

- jövedelmi egyenlőtlenség,

- szegénység vagy társadalmi kirekesztettség kockázatának kitettek száma (AROPE),

- nem dolgozó, nem tanuló fiatalok aránya (NEET);

- tisztességes munkafeltételek:

- foglalkoztatási szint,

- munkanélküliségi ráta,

- munkaerőpiaci aktivációs intézkedések (a legfrissebb információk szerint nem lesz része a JER-beli értékelésnek),

○ háztartási bruttó jövedelem,

- bérek és bérjellegű juttatások (a legfrissebb információk szerint nem lesz része a JER-beli értékelésnek);

- szociális védelem és a társadalmi befogadás:

- a szociális védelmi kiadások (nyugdíjak kivételével) szegénységcsökkentő hatása,

- 3 évnél fiatalabbak bölcsődei részvétele,

○ ki nem elégített egészségügyi szolgáltatási szükséglet,

- digitális készségek szintje.

Amint látszik, a 20 cél nem mindegyikéhez létezik kulcsindikátor $(7,8,10,18)$, és közelebbről is megnézve az is nyilvánvaló, hogy az egyes kulcsindikátorok nem fedik le teljesen az adott célt, azaz csupán korlátozott relevanciával bírnak az adott cél tekintetében; néhányan azonban több célt is mérnek. Néhány indikátor értelmezése (pl. aktív munkaerőpiaci eszközökben való részvétel) nem egyértelmü, azaz nem biztos, hogy a magasabb vagy az alacsonyabb érték jelenti a valóban jó teljesítményt, hiszen figyelembe kell venni az adott ország egyéb körülményeit (pl. a közszolgáltatások kiterjedtsége és jellegzetességei, a gazdaság szerkezete, párhuzamos eszközök alkalmazása stb.) is. Több indikátor esetében korlátozott az összehasonlíthatóság és a statisztikai megbízhatóság, míg néhány ország esetében nem áll rendelkezésre minden mérőszám. 
Az Európai Bizottság az értékelés során - egyelőre nem állít fel referenciaértékeket, amelyekhez viszonyítaná az országok teljesítményét. Az országok nyílt összehasonlítása se történik meg, hanem a tagországokat - a JER elfogadott módszertana alapján - 7 csoportba (kritikus; figyelendő; gyenge, de javuló; átlagos/semleges; jó, de figyelendő; átlagnál jobb; legjobban teljesítő) sorolják az egyes mérőszámok tekintetében, és figyelik az éves változásokat is. Egy előzetes, csak a 14 indikátoron végzett értékelés szerint Magyarország kevés indikátort tekintve van a kritikus helyzetben lévők között, de a legjobbak csoportjában is csak egy indikátorral - a sokat vitatott aktív munkaerőpiaci eszközökben való részvétel tekintetében - szerepel.

\section{Az egészség megjelenése a pillérben}

A tág értelemben vett egészség témája több helyen is megjelenik a pillér célkitűzései között. Az egészséges, biztonságos és megfelelően kialakított munkakörnyezet (10. cél, de ehhez nincs kulcsindikátor), a megfelelő egészségügyi ellátáshoz való jog (16.), a megfelelő tartós ápolás-gondozás (18., ehhez sincs kulcsindikátor) közvetlenül, míg a fogyatékossággal élő személyek társadalmi befogadása (17.) és az alapvető szolgáltatásokhoz való hozzáférés (20.) közvetve szól az egészségről is. Az ezekhez tartozó egyetlen kulcsindikátor, a ki nem elégített egészségügyi szolgáltatási szükséglet időbeli alakulását az 1. táblázat mutatja.

Ezzel az indikátorral Magyarország viszonylag jó eredményt tud felmutatni, de ez nem jelenti azt, hogy hazánkban abszolút értelemben jó minőségű lenne az egészségügyi ellátás. Az összehasonlítás további korlátját jelenti, hogy az adatok több esetben elég megbízhatatlanok, ugyanakkor nagy vonalakban tükrözik a vélelmezett valóságot. A pillér egészségre és egészségügyi ellátásra vonatkozó megállapításai nem helyettesítik sem a JAF Health indikátorrendszer alapján végzett kísérleti országelemzést, sem a már ismert és bejáratott országelemzéseket (OECD, European Observatory on Health Systems and Policies).

Az Európai Bizottság eredeti javaslatában még szerepelt a „készpénzes egészségügyi kiadások aránya" indikátor is, ez azonban egyelöre - lévén inkább strukturális mérő - a többi másodlagos indikátorral együtt elutasításra került.
Amint látható, az egészségi jogok nem elsősorban a jó egészségi állapotot (és annak eredményét, pl. az egészségben eltöltött éveket), hanem az ehhez szükséges szolgáltatásokhoz való hozzáférést jelentik. Szintén hiányzik a megfelelő környezetre, valamint a prevencióra való utalás.

\section{A pillér Magyarország szempontjából}

Magyarország szempontjából némiképp hátrányos, hogy a társadalmi kohézió megteremtése érdekében a szociális pillér ugyan támogatható lesz uniós forrásokból, azonban a kohéziós politika keretében a prioritás nem a legkevésbé fejlett régiók (KözépKelet-Európa) segítése lesz, hanem a legnagyobb szociális problémákkal küzdő tagállamok (főleg DélEurópa) kiemelt támogatása. Aggályos továbbá a szociális sztenderdek felé történő konvergencia lehetséges kikényszeríthetősége az európai szemeszterbe való fokozatos beágyazás által, amit az Európai Bizottság elnöke 2017 őszén megerősített, de általános döntés még nem született róla. Ezzel párhuzamosan látható, hogy a szemeszter, amely eddig elsősorban a gazdaságpolitikai koordinációnak adott terepet, egyre inkább magába foglal szociális kérdéseket is, amelyek eddig leginkább a gazdaságpolitikának alávetetten szerepeltek, és úgy tekintettek rájuk, mint amelyek hátrányosan érintik a gazdasági versenyképességet.

\section{Várható hatások, a pillér jövője}

Amint látszik, számos kérdés tisztázatlan még a pillérrel kapcsolatban. Meghatározó lesz, ahogy az Európai Bíróság, illetve más jogalanyok hivatkoznak majd rá. Szintén nem végleges még az előrehaladást mérő és mutató szociális eredménytábla, amelynek jelenlegi változata számos hiányosságot és kompromisszumot hordoz. Mindezek alapján várhatóan szükség lesz az Európai Unió statisztikai rendszerének továbbfejlesztésére. Az is kérdéses, hogy a mutatószámok bizonyos (negatív) alakulása milyen következményekkel jár, például milyen mélységben szerepelnek majd hivatkozási alapul az Európai Szemeszterben. További kérdéseket vet fel a pillérrel ugyan egyet nem értő, de azt elutasítani mégsem akaró országok tényleges magatartása.

A pillér tényleges hasznosulása tehát csak a gyakorlat ismeretében dönthető el. 
1. táblázat: A megfelelő egészségügyi ellátáshoz való jog és az alapvető szolgáltatásokhoz való hozzáférés a ki nem elégitett egészségügyi szolgáltatási szükséglet (túl drága, messze van, vagy hosszú várakozási lista; 16 éves vagy idősebb népesség, \%) indikátorral mérve

\begin{tabular}{|l|l|l|l|l|l|l|l|l|l|l|}
\hline ország / év & 2008 & 2009 & 2010 & 2011 & 2012 & 2013 & 2014 & 2015 & 2016 \\
\hline Belgium & 0,5 & 0,6 & 0,4 & 1,5 & 1,7 & 1,9 & 2,5 & 2,4 & 2,4 \\
\hline Bulgária & 15,3 & 10,3 & 10,5 & 9,8 & 8,3 & 8,9 & 5,6 & 4,7 & 2,8 \\
\hline Csehország & 0,7 & 0,6 & 1,0 & 1,1 & 1,0 & 1,0 & 1,1 & 0,8 & 0,7 \\
\hline Dánia & 0,6 & 1,5 & 1,1 & 0,9 & 1,3 & 1,3 & 1,4 & 1,3 & 1,3 \\
\hline Németország & 2,2 & 2,1 & 1,8 & 1,7 & 1,6 & 1,6 & 1,6 & 0,5 & 0,3 \\
\hline Észtország & 7,3 & 4,3 & 4,8 & 7,3 & 8,3 & 8,4 & 11,3 & 12,7 & 15,3 \\
\hline Írország & 1,8 & 2,0 & 2,1 & 2,2 & 3,4 & 3,3 & 3,7 & 2,8 & 2,6 \\
\hline Görögország & 5,4 & 5,5 & 5,5 & 7,5 & 8,0 & 9,0 & 10,9 & 12,3 & 13,1 \\
\hline Spanyolország & 0,4 & 0,5 & 0,3 & 0,6 & 0,7 & 0,8 & 0,6 & 0,6 & 0,5 \\
\hline Franciaország & 1,9 & 1,9 & 1,9 & 2,3 & 2,2 & 2,6 & 2,8 & 1,2 & 1,3 \\
\hline Horvátország & $:$ & $:$ & 6,3 & 5,1 & 3,5 & 3,3 & 3,3 & 1,9 & 1,7 \\
\hline Olaszország & 5,2 & 5,4 & 5,2 & 5,9 & 5,7 & 7,0 & 7,0 & 7,2 & 5,5 \\
\hline Ciprus & 2,8 & 3,4 & 4,1 & 4,4 & 3,5 & 4,4 & 4,7 & 1,5 & 0,6 \\
\hline Lettország & 9,9 & 9,9 & 15,1 & 16,1 & 12,4 & 13,8 & 12,5 & 8,4 & 8,2 \\
\hline Litvánia & 5,7 & 3,1 & 2,6 & 2,8 & 2,3 & 3,2 & 3,7 & 2,9 & 3,1 \\
\hline Luxemburg & 0,6 & 0,6 & 0,6 & 0,6 & 0,7 & 0,9 & 0,8 & 0,9 & 0,4 \\
\hline Magyarország & 3,4 & 2,1 & 1,7 & 2,7 & 2,9 & 2,6 & 2,5 & 2,6 & 1,3 \\
\hline Málta & 0,7 & 1,4 & 1,6 & 1,1 & 1,2 & 0,9 & 1,1 & 0,8 & 1,0 \\
\hline Hollandia & 0,3 & 0,3 & 0,4 & 0,4 & 0,5 & 0,4 & 0,5 & 0,1 & 0,2 \\
\hline Ausztria & 0,7 & 0,5 & 0,6 & 0,4 & 0,3 & 0,4 & 0,1 & 0,1 & 0,2 \\
\hline Lengyelország & 6,0 & 7,6 & 8,3 & 7,9 & 9,0 & 8,8 & 7,8 & 7,3 & 6,6 \\
\hline Portugália & 1,1 & 3,3 & 2,0 & 1,4 & 3,3 & 3,0 & 3,5 & 3,0 & 2,4 \\
\hline Románia & 11,1 & 8,9 & 11,1 & 12,2 & 11,5 & 10,9 & 9,8 & 9,4 & 6,5 \\
\hline Szlovénia & 0,2 & 0,2 & 0,1 & 0,1 & 0,1 & 0,0 & 0,2 & 0,2 & 0,4 \\
\hline Szlovákia & 1,3 & 1,7 & 1,7 & 2,2 & 2,2 & 1,9 & 2,1 & 2,1 & 2,3 \\
\hline Finnország & 0,8 & 3,7 & 3,9 & 4,4 & 4,6 & 4,3 & 3,3 & 4,3 & 4,1 \\
\hline Svédország & 2,4 & 2,0 & 1,8 & 1,4 & 1,4 & 1,9 & 1,5 & 1,3 & 1,6 \\
\hline Egyesült Királyság & 1,0 & 1,2 & 1,0 & 1,2 & 1,4 & 1,6 & 2,1 & 2,8 & 1,0 \\
\hline
\end{tabular}

Forrás: http://appsso.eurostat.ec.europa.eu/nui/show.do?dataset=hlth silc 08\&lang=en 